\title{
Tell Abu Hafur 'East', Tell Arbid (Northeastern Syria), and Nemrik (Northern Iraq) as Examples of Small-Scale Rural Settlements in Upper Mesopotamia in the Mittani Period
}

\section{o. Introduction}

For a long time our knowledge of Mittani settlement in upper Mesopotamia was based mainly on the excavations at Yorgan Tepe (Nuzi) and the information obtained from the texts found there; yet this region lying to the east of the Tigris River was the peripheral, eastern limit of the Mittani Kingdom. Knowledge about the mid-second millennium BC settlement landscape of the Jazirah, especially of the Syrian Jazirah, which was the heartland of the Mittani Kingdom, remained scarce until the end of the I970s. For a long time basic information concerning the settlement history of this vast region was based on descriptions made by $\mathrm{I}^{\text {th }}$ century travelers ${ }^{\mathrm{I}}$ and on surveys carried out in the I930s and I950-I960s. ${ }^{2}$ However, those surveys concentrated mainly on large and easily visible tells, so small and flat sites, often situated in ploughed fields, were overlooked or omitted. It was a similar case with the choice of sites for excavations, as the main interest of the excavators was focused on large sites, which constituted a much more attractive and promising target. 3 If remains of Mittani-period occupation on the large tells were present, they were often difficult to access because of an accumulation of later deposits or were badly preserved, which discouraged excavators from exploring them further.

Investigations of the settlement history of northern Mesopotamia and especially of the Jazirah have intensified since the end of the I970s, as various salvage excavations have been carried out, due to several dam projects on the Tigris, 4 Euphrates, 5 and Khabur 6 rivers in Iraq, Syria, and Turkey. The areas of the dam reservoirs were intensively surveyed and a large number of different sites were excavated.

Rekindled interest in the investigations of the Syrian Jazirah appeared with the restarting of excavations at Tell Brak in 1978.7 The emerging picture of settlement landscape was enhanced by a series of new and more detailed surveys ${ }^{8}$ and new excavations. 9 All this has made it possible to identify a substantial number of small and medium-sized sites that date to the Mittani period (mainly I $4^{\text {th }}$ century BC) and to obtain more information about the character of settlement in this period.

\footnotetext{
Listed by Meijer I986, 2-3.

Poidebard I934; Mallowan 1936; van Liere / Lauffray I954-I955; van Liere I963.

3 Tell Halaf (І9Іі), Tell Shagar Bazar, and Tell Brak (I935, I937), Tell Fekheriye (I940), Tell Chuerra (1958), Tell al Rimah (1964).

4 Eski-Mosul/Saddam Dam Salvage Project (Iraq, I980I990), Ilısu Dam Project (Turkey, since I998).

5 Tishrin Dam Project (Syria, since I99I), Carkemish Dam Project (Turkey, since I998).

6 Western Hassake Dam (1985-1990) and the Middle Khabur Dam South of Hassake (since I986-I998).
}
7 Sheikh Hammad (Dūr-Katlimmu) since I979, Tell Barri (Kahat) I980, Tell Mozan (Urkeš) I983, Tell Hamidiye (Taidu) I984, Tell Mohammad Diyab I987, Tell Hazna I9 88 .
8 E.g., in the vicinities of Tell al-Hawa (Ball et al. I989), Tell Beydar (Wilkinson 2002), Tell Hammoukar (Ur 20IO, III-II2), and the areas of the Balikh Valley (Lyon 2000) and the Khabur Triangle (Lyonnet / Faivre 20I3).
9 Tell Beydar since i992, Tell Arbid I996, Tell Hammou- kar 1999 .




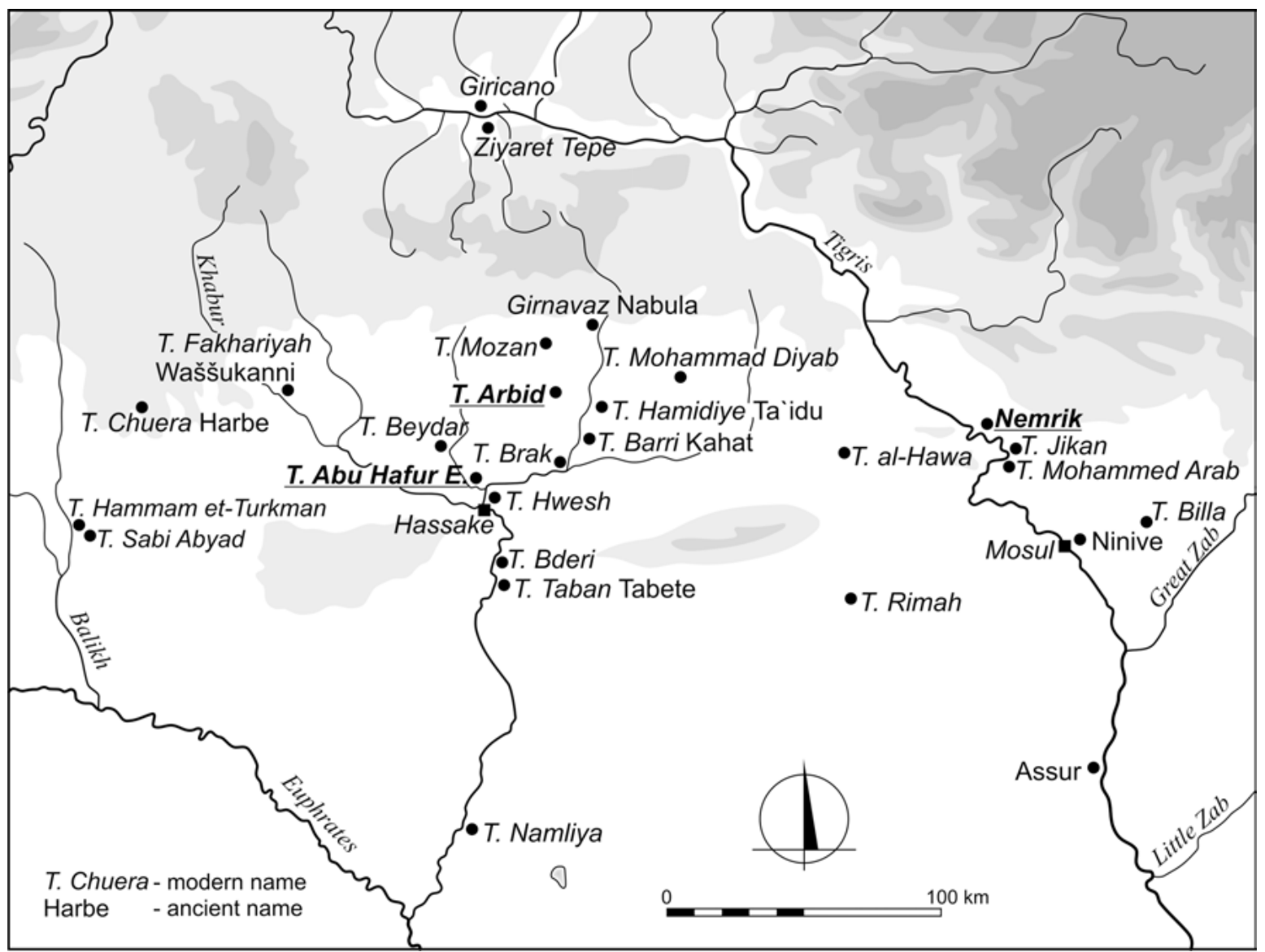

Fig. 1 | Upper Mesopotamia in the Mittani period (excavated sites): Harbe = Ancient name, T. Chuera = modern name, T. = Tell, Nemrik $=$ site described in the article (Compilation and digitization Marta Momot).

Since 1979, excavation teams of the Polish Center of Mediterranean Archaeology at the University of Warsaw have been taking part in these activities. This has allowed us to unearth, among others, three sites with remnants of Late Bronze Age occupation, namely Tell Abu Hafur 'East' and Tell Arbid in Syria, and Nemrik in Iraq, which have proved to be valuable sources of information on the settlement history of the Mittani period.

\section{Tell Abu Hafur 'East' '}

Tell Abu Hafur 'East' was situated on the left bank of wadi al-A'awaj ca. $80 \mathrm{~m}$ to the east of Abu Hafur, a huge tell which was occupied in the fourth and third millennia BC. Occupation of the small eastern tell (ca. I.5 ha and $5 \mathrm{~m}$ high) began in the Mittani period and, after several centuries, it was resettled in the Neo-Assyrian period and again in Hellenistic and Parthian times.

Io The site was excavated during two seasons in 1989 and I990 by a team directed by Piotr Bielinski as part of the rescue excavation of the Basin of the Western Hassake
Dam built on the Khabur River (Bieliński I99I, I0I). See also: Pfälzner 1995, I74, Reiche 1997, and Anastasio et al. 2004,38 . 

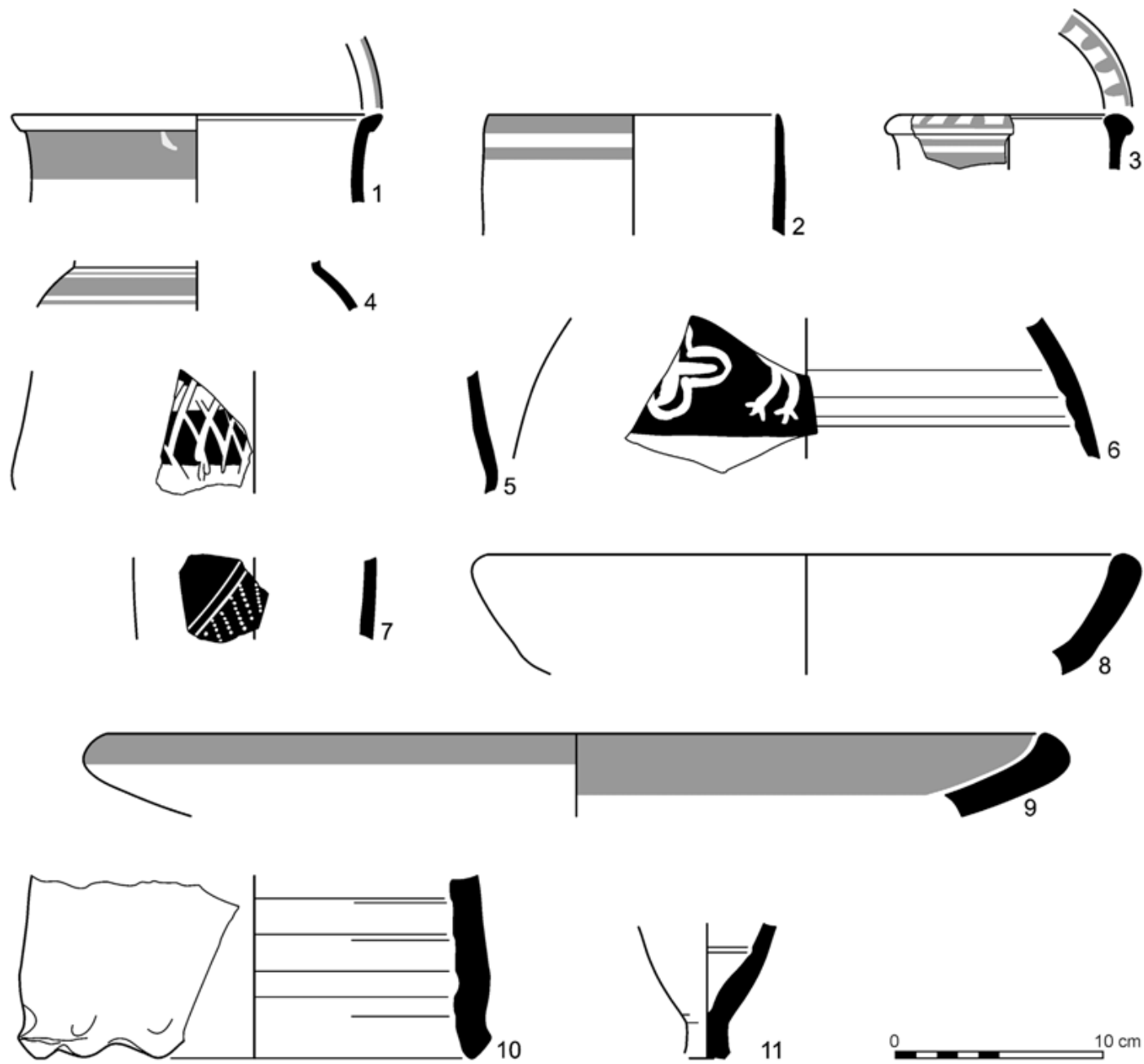

Fig. 2 | Tell Abu Hafur 'East' - Mittani-period pottery (Digitization Marta Momot).

Remnants of at least two Mittani occupation phases were revealed in a test trench on the western slope of the site, bordering the nearby wadi. A fragment of a house with mud-brick walls preserved to a height of $c a .0 .50 \mathrm{~m}$ was cut by this trench. The house was built upon a thin layer of debris from the Late Bronze Age, covering the virgin soil. In the test trench, which extended to the foot of the tell, no traces of de-

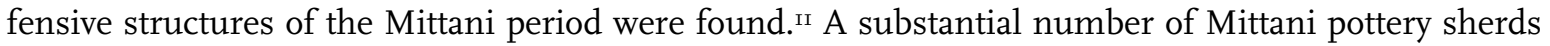
were found scattered along the western slope and on the surface of the site.

Further unearthing of this interesting site, however, was made impossible due to the end of the rescue excavations.

Among the collected pottery fragments were examples of the Younger Khabur Ware (fig. 2:I-4), Nuzi Painted Ware (fig. 2:5-7), Grey Burnished Ware (fig. 2:8), red-edged bowls (fig. 2:9), 'pie-crust potstands' (fig. 2:I0), and footed beakers (fig. 2:II). ${ }^{\mathrm{I2}}$ In the layer of the older phase, painted sherds of the

II Later in the Neo-Assyrian period a defensive wall did exist in that part of the site (Reiche $1997,361-362$ ).
Terms used for the description of different categories of Mittani pottery follow those defined by Pfälzner in 2007. 
Younger Khabur were more numerous than in the later phase. This observation allowed us to postulate a dating for the beginning of this settlement in the Middle Jazirah I A period, while its second phase belongs mainly to the Middle Jazirah I B period. ${ }^{\mathrm{3}}$ However, one should bear in mind that this interpretation is based only on a limited sample of collected potsherds.

Tell Abu Hafur 'East' was not the only Mittani rural settlement in the lower course of wadi al-A'awaj. Surface finds from unexcavated small satellite tells lying in close vicinity to the third millennium BC tells, such as Jassa el-Gharbi and Abu Hijarah, confirmed the presence of smaller villages in the region to the west of Hassake during the Mittani period. To those villages one should also add Tell Hwesh, a small rural site (a farmstead) lying further to the east, on the left bank of the Jaghjagh River, some $5 \mathrm{~km}$ to the north of Hassake (Pfälzner I990; I995, I73). A Mittani-period settlement was found also in the upper run of wadi al-A'awaj, in the 'lower town' (field J) of Tell Beydar (Bretschneider 1997). This site had a similar chronological sequence to that of Tell Abu Hafur 'East', Tell Hwesh, and other small sites along the lower Khabur listed by Peter Pfälzner (I995, I69-I72). .14 Common features shared by those sites were: their small to medium size, the presence of pottery dated to the $14^{\text {th }}$ century $\mathrm{BC}$, and the fact that they were new settlements and were not occupied in the succeeding Middle Assyrian period (Pfälzner I995, 223, 225), but were instead often resettled in the Iron Age.

\section{Tell Arbid 15}

The site of Tell Arbid lies in the northeast of Syria in the centre of the Khabur Triangle, at a distance

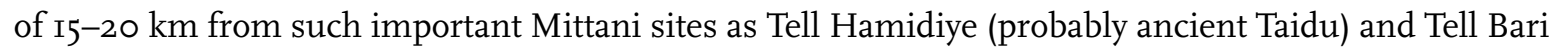
(ancient Kahat) to the southeast, Tell Brak (ancient Nagar) to the south, and Tell Mozan (ancient Urkeš) to the north.

The site consists of the main tell with a high citadel encircled by a lower town and three small satellite tells lying within a $c a .60 \mathrm{~m}$ radius to the west of the main mound. The ancient occupation of the site extended, with some stratigraphic gaps, from the Halaf to the Neo-Babylonian and Hellenistic periods, with the largest extension in the Early Jazirah III A (= Late Ninevite 5) period in the first half of the third millennium BC. In later periods, occupation on a smaller scale can be observed but it is restricted to some areas of the site.

Although no occupation remnants of the Middle or Neo-Assyrian periods were found in the excavated areas, it should be noted that during the upper Khabur survey carried out by Bertille Lyonnet, a number of Middle Assyrian pottery fragments were collected on the site (Anastasio 2007, I4I). It is possible that they came from the southern unexcavated satellite tell that has been heavily destroyed by modern ploughing.

Remnants of the Mittani occupation at Tell Arbid were found in two places - on the western satellite tell (sector A) and on the top of the main tell (sector SA).

I3 For a discussion of a periodization of Late Bronze Age Pottery see recently Pfälzner 2007.

I4 Tell Abu Bakr, Tell Kerma-South, Tell Maraza, and Tell Namliya.
I5 The site has been excavated since I996 by a Polish-Syrian mission directed by Piotr Bieliński and Ahmad Serriye (until 2006) and now Abd al-Masih Bagdo. The results have been published in excavation reports by Bieliński in: Polish Archaeology in the Mediterranean [PAM]. Reports (eds. M. Gawlikowski, W.A. Daszewski) since I997. 


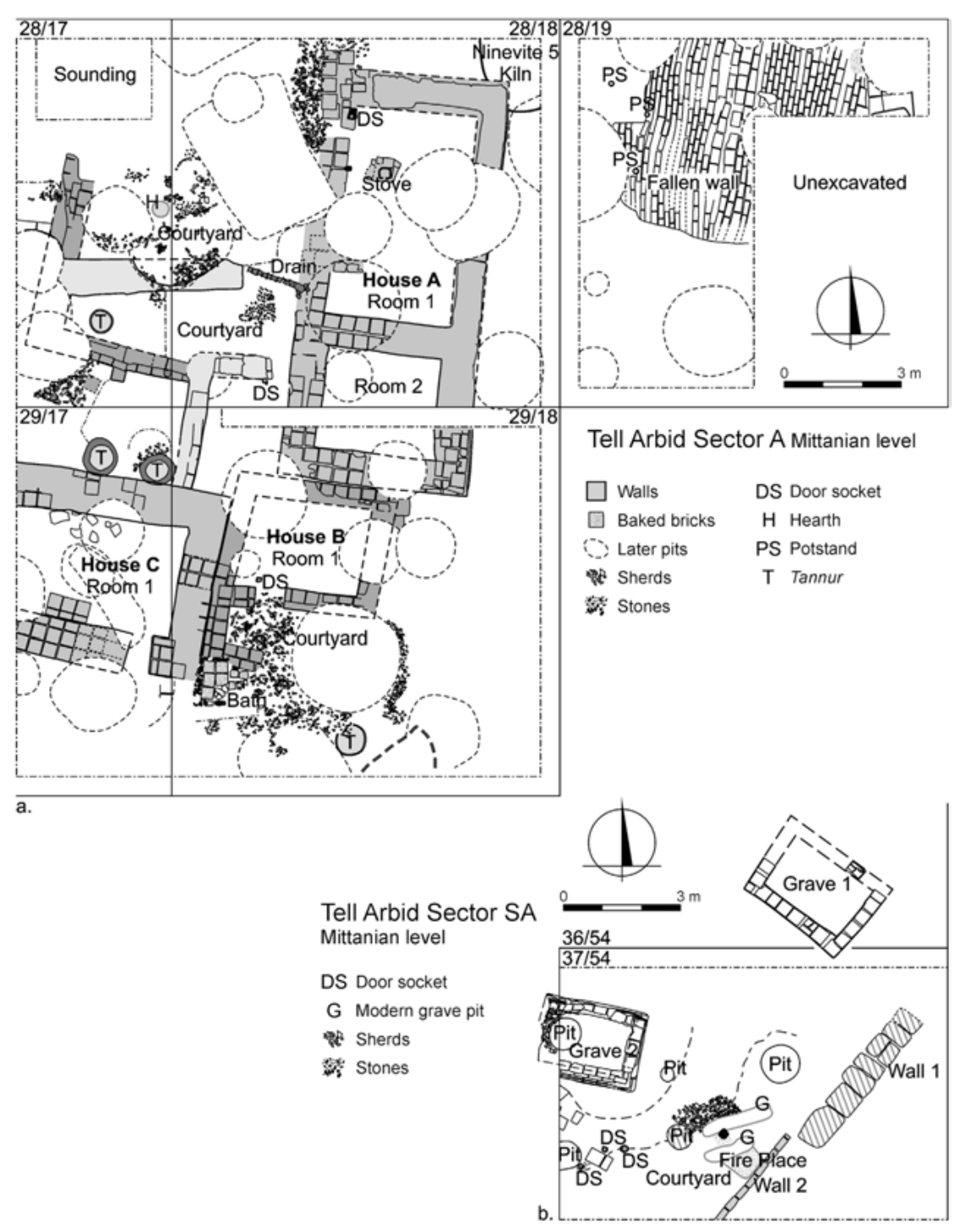

Fig. 3 | Tell Arbid-Mittani-period structures (a. Sector, b. Sector SA). (3a Drawing: Piotr Bieliński, Rafał Koliński, Joanna Lorynowicz, Marta Momot, Andrzej Reiche, Agnieszka Szymczak; digitization Marta Motot;

3b. Drawing: Joanna Lorynowicz, Marta Momot, Anna Smogorzewska; digitization: Marta Momot).

\subsection{Mittani settlement on the satellite tell (sector A)}

In sector A an unfortified small-sized rural settlement, covering an area of $c a .2$ ha, was founded on top of the remnants of Early Jazira III A structures. A fragment ( $\left.c a .450 \mathrm{~m}^{2}\right)$ of the settlement was unearthed in the western part of the tell, uncovering dense domestic architecture. Despite the fact that this satellite tell was badly damaged by Hellenistic storage pits and by a large pit dug by the villagers in modern times, one almost complete house (labelled 'Northern House'), and parts of two others, were unearthed.

The 'Northern House' had a rectangular plan $($ I $0.70 \times 4.80 \mathrm{~m})$ oriented north-northeast-southsouthwest, and was divided into two unequally sized rooms. In the larger one a heating stove placed on a small mud-brick platform was unearthed. The entrance at the northern end of the western wall led to a large courtyard (at least $40 \mathrm{~m}^{2}$ ) paved with potsherds and gravel. The yard, sloping slightly westwards, was encircled by a mud-brick wall of which only a fragment of the southwestern corner remained. 
An interesting installation in the 'Northern House' was a drain, designed to carry water away from the room to the courtyard. It was made from a fragment of a pipe and reused 'pie crust pot-stands'. Unfortunately, the end inside the room was destroyed by the bottom of a Hellenistic pit, so the context of its function remains unknown.

The two partly preserved houses, located to the south of the building described above, had an eastwest orientation and were facing south. The 'South-Western House' differs from the other two: firstly, it was founded on a step lying ca. $0.40 \mathrm{~m}$ lower; secondly, its walls were two and a half bricks wide and therefore wider than those in the 'Northern House'. Its entrance was uncovered in the southern wall close to the southeast corner. Inside the room was a small mud-brick platform placed at the southern wall and on the floor were scattered fragments of a large storage jar. Because only a part of this house was excavated it is hard to say whether differences mentioned above were the result of a non-domestic function.

The 'South-Eastern House' (preserved only in its western part) seems to have been built later, since its narrow walls, only one and a half bricks wide, were fitted exactly into a corner space that was left behind the two houses described above. In the western end of its southern wall an entrance led to a courtyard paved with potsherds and gravel. At the southern end of the house's western wall, remnants of a small rectangular bath $(\mathrm{I} \times 0.70 \mathrm{~m})$ were unearthed. Its floor and a drain leading to the courtyard were made of baked bricks. To prevent water-damage to the walls, their junction with the floor was lined with stones.

A puzzling feature was found in the northeastern square. It was a large fragment of a fallen wall ( $6.6 \mathrm{~m}$ long from east to west and $5.2 \mathrm{~m}$ wide from north to south), composed of at least 36 rows of bricks, allowing us to reconstruct a wall over $3 \mathrm{~m}$ in height. It seems that the wall fell down on its western face, which would mean that there was an empty space over $6 \mathrm{~m}$ wide between the 'Northern House' and the building to which the fallen wall belonged.

Some very fragmentarily preserved walls belonging to the Mittani level, overlying remnants of Early Jazirah III A occupation, were also unearthed in a trench located at the eastern end of sector A. This finding confirmed the presence of Mittani occupation also in the eastern part of the satellite tell.

\subsection{Mittani occupation on top of the main tell (sector SA)}

On top of the main tell a thin layer of Mittani occupation was preserved in the form of scarce remnants of a courtyard with a rectangular fire-place and two storages pits ( $\mathrm{m}$ in diameter and ca. $2 \mathrm{~m}$ deep) placed directly upon the Khabur-period ruins. Severe erosion of the summit and the destruction caused by a post-Hellenistic cemetery made it hard to determine the range and character of the Mittani occupation. With its area not exceeding o.I ha it could be nothing more than a single farmstead, but its localization on the summit of the tell may suggest that it could have a defensive character.

The findings from both the satellite tell and the summit were homogeneous. The pottery found corresponded to the pottery assemblages of the Middle Jazirah I B period (between I400/1350 BC and I270 BC) (Pfälzner 2007, 236). It contained a few examples of Younger Khabur Ware (fig. 4:I3, I6), burnished red-edged bowls (fig. 4:IO-II), 'pie-crust pot-stands' and bottom parts of footed beakers with vertical walls. A significant feature was a large number of sherds of luxury Nuzi painted pottery, mostly beaker fragments (fig. 4:6-9, I4, I5,) but also fragments of other vessel types with Nuzi painted decoration (fig. 4:I7). 
Fig. 4 | Tell Arbid - Mittani-period small finds and pottery. (Drawing: Marta Momot, Aleksandra Pęska; digitization: Marta Momot).

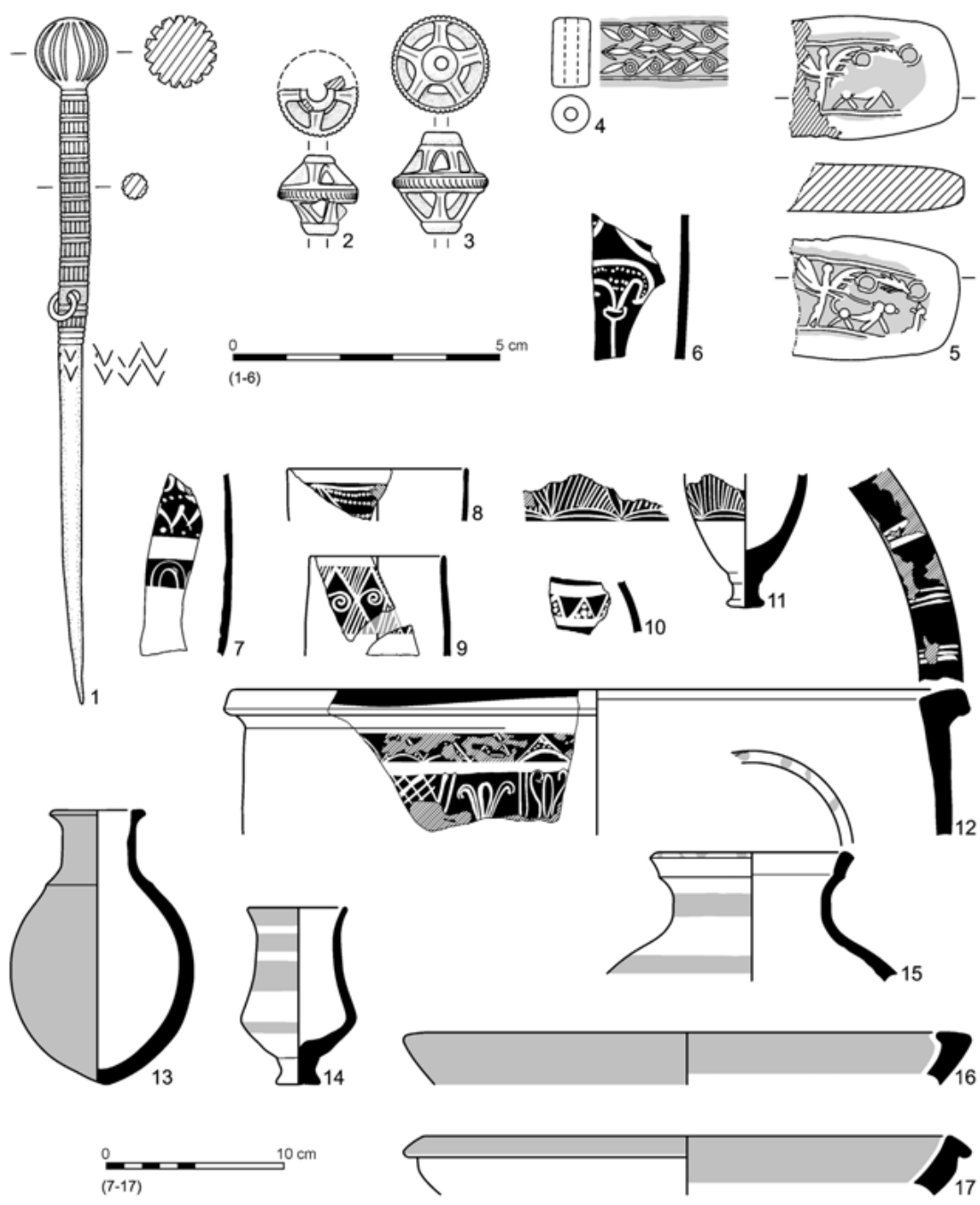

Two biconical or wheel-shaped openwork beads made of faience were also found in both places of settlement (fig. 4:2-3). They were most probably a Mycenaean import but one cannot exclude the possibility of local imitations. ${ }^{16}$ Single examples of such beads, dated to the late $14^{\text {th }} / 13^{\text {th }}$ century BC, were found in northeastern Syria in the Mittani context at Tell Brak ${ }^{17}$ and Tell Bazi. ${ }^{18}$ According to Lorenz Rahmstorf's study "openwork beads should be considered precious artifacts deposited only in rich burials or placed in the recurring set of objects used in cult actions". He noted, however, that "no strict functional limitation for these beads to either a cult or profane sphere can be postulated" (Rahmstorf 2005, 666). The two Tell Arbid examples were found in occupation layers without any architectural connections.

A fragment of a docket with an impression of the same seal on both sides (fig. 4:5) was found in the courtyard of the 'Northern House'. The seal impression belongs to the group of so-called 'Syro-Mittani' glyptic-style seals (dated ca. I450-I300 BC) with a characteristic depiction of a standing winged demon surrounded by lying animals and filling motifs including a scorpion (Teissier I984, 291:608).

I6 Rahmstorf (2005) presented a comprehensive study of this type of beads, which have been found on sites from Italy to north-eastern Syria, but most of them (over 53) in Greece; see also Rahmstorf 2008, 223-226.
I7 One example found in a store room of the Mittani Palace (McDonald I997, I02, figs. 134, 225:67).

I8 One example (Otto 2006, I27, fig. 66,6). 


\subsection{Mittani graves}

On the northern slope of the summit two Mittani chamber-graves built of sun-dried mud bricks were also found. Each grave contained a female burial and yielded rich and luxurious grave goods indicating that the buried persons held a high social status. The first grave (Smogorzewska 2006) contained among other things a set of $\mathrm{I} 6$ pottery vessels, one glass beaker, two cylinder seals (one of haematite executed in the Elaborate Style and one of faience in the Common Style), a very rich set of jewellery consisting of $c a .300$ beads and pendants of various shapes, made of different materials including gold, ivory, and semi-precious stones, a faience scarab of Palestinian provenance and an ivory scaraboid with Egyptian hieroglyphs.

The second grave (Bieliński 2003, 28I-282) contained a similar number of different pottery vessels, two Common Style cylinder seals (one made of faience (fig. 4:4) and the other of glass), a handful of beads, and a unique set of two almost identical toggle pins made of silver and partly gilded (fig. 4:I): ${ }^{19}$ a sheep offering was also placed in the grave.

The dating of the objects found in both graves was not congruent. There were items dated to $c a$. I450-I300 BC, e.g., the cylinder seals (Smogorzewska 2006, 78-80, fig. 8:I, 2), but both graves also contained objects of an earlier date, e.g., the scarab and the scaraboid dated to the $16^{\text {th }}-15^{\text {th }}$ century BC

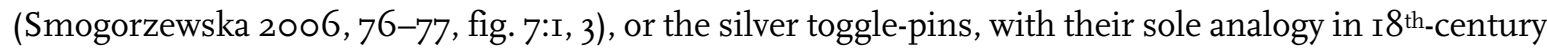
BC.

In the pottery assemblages from both graves, too, a mixture of older and younger vessel types was observed, e.g., a Red Slipped Ware bottle characteristic of Middle Jazirah I B pottery (fig. 4:I2, Grave 2) and shouldered beakers of Younger Khabur Ware (fig. 4:I3, Grave 2, and Smogorzewska 2006, 72, fig. 3 : 5, Grave I). Such beakers are typical of the Middle Jazirah I A pottery. Surprisingly, the shouldered beakers were not found in the settlement context, whereas the Nuzi painted beakers were completely absent from the grave assemblages, but abundant in the former context.

Rich grave goods found in the burials, as well as luxurious finds from the settlement (e.g., Nuzi painted pottery, openwork faience beads) indicate that the Mittani village was inhabited by a rich family of high social status. Taking this into consideration one can make the supposition that, from a socioeconomic point of view, the Mittani settlement at Tell Arbid functioned as an 'extended family commune' or 'extended household'. ${ }^{\circ}$

The site lies in an area where dry-farming was possible, the major crop being most probably barley, and sheep and goats could also be herded by its ancient inhabitants. The richness visible especially in the grave goods may suggest that agriculture did not constitute the only source of income for the owner of this household. Of course, without any written documents such an interpretation is only a matter of conjecture.

I9 This type of pins was typical for the Middle Bronze Age (Klein, I992 I04, Type I Ir B2c). Examples of pins made of silver are known only from a grave of the karum level Ib at Kaneš/Küh/Kultepe (Maxel-Hyslop I97I, 99:74). One example of gilding, but on a bronze pin, was found at Tell Halawa (Novak I994, 239, No. 26).
An elaborate discussion of the first term based on Nuzi texts was presented in Dosch I996, 302-303; for the second term, in opposition to Dosch, see Koliński 200I, I9, n. 20 


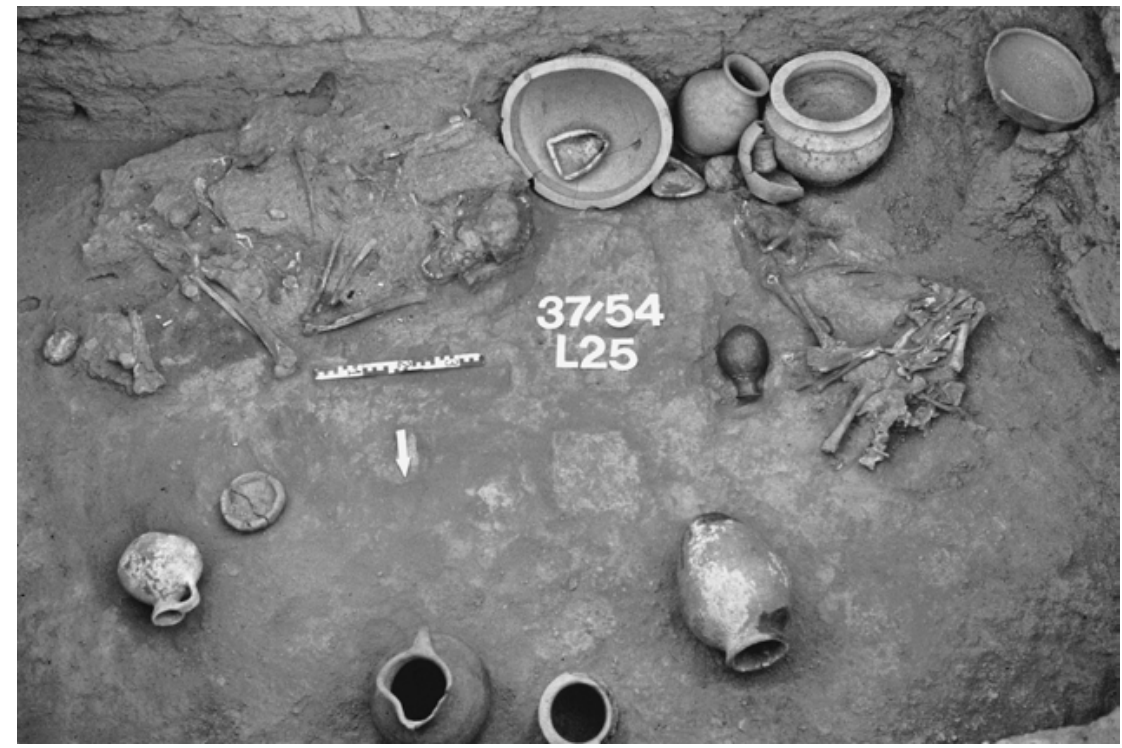

a.

Fig. 5 | Tell Arbid - Mittani Grave 2. a. The burial chamber with grave goods in situ.

b. The set of pottery from the grave.

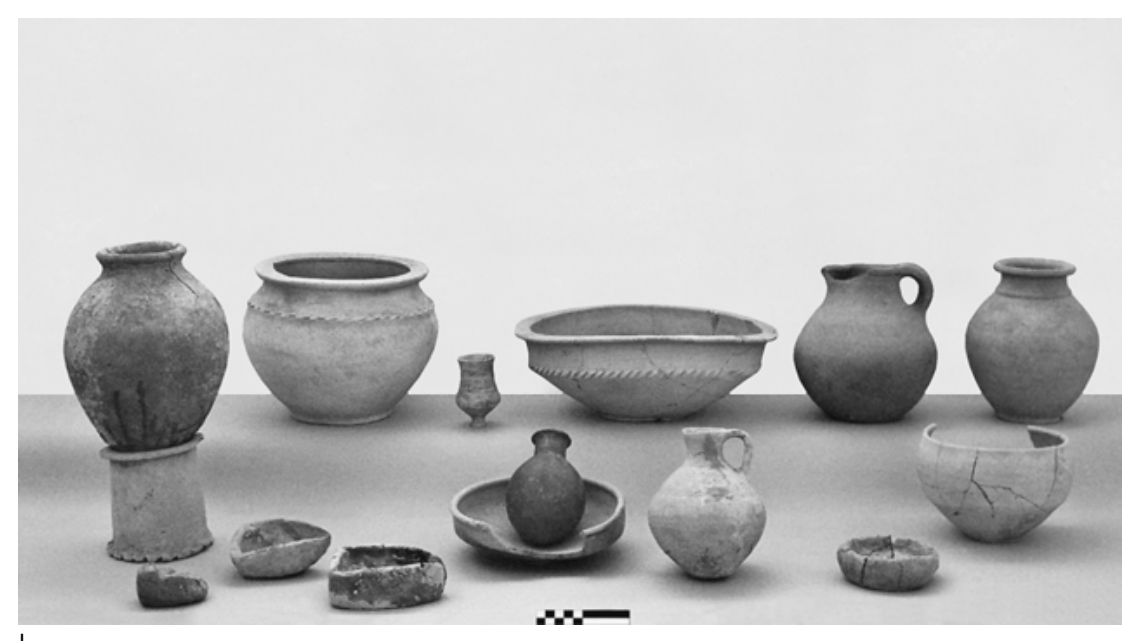

b.

\section{Nemrik ${ }^{21}$}

Nemrik lies in Northern Iraq, $c a .50 \mathrm{~km}$ north of Mosul and $c a .4 .3 \mathrm{~km}$ southwest of the village of Faidah. It is located on a river terrace on the eastern side of the Tigris valley, $c a .1 .5 \mathrm{~km}$ away from the former river bank. The surface of the plateau is flat but numerous gullies, running down towards the river valley, are a characteristic feature of the landscape. The site was occupied for the first time in the Early Neolithic period (the eighth and seventh millennia BC) as a village with several round houses covering an area of at least I. 8 ha.

$2 \mathrm{I}$ Saddam Dam Salvage Project were carried out in the
years $1985-1989$ by the mission directed by Stefan K. Kozłowski. The main purpose of these rescue exca- vations was the investigation of an Early Neolithic village, while the excavation of Late Bronze Age remains constituted an additional task (Reiche I990); see also Reiche in print. 
Following a long period of abandonment, the site was occupied again in the Late Bronze Age, first in the Mittani period and, after a lengthy break, in the Middle Assyrian period. The Late Bronze Age occupation was restricted to the southeastern part of the site and covered an area of at least 30 ha. It should be stressed that the Middle Assyrian occupation of the site did not exceed the limits of the previous Mittani settlement. ${ }^{22}$

After its abandonment, the site was used as a cemetery for an undetermined period (comprising pre-Islamic graves, without grave goods). At present, the Late Bronze Age tell is so heavily eroded that occupation deposits are only preserved to a height of $0.80 \mathrm{~m}$.

\subsection{The Mittani settlement}

A fortified settlement, restricted to the southeastern end of the site, was founded directly upon the eroded Neolithic deposits. From the northeast and east it was protected by the steep slopes of a $c a .30 \mathrm{~m}$ deep wadi, from the south by an erosion gully some I $2 \mathrm{~m}$ deep, while the west and northwest ditches had been dug out. At the western limit of the settlement, a defensive wall with a I $m$ wide stone foundation was erected. Its course followed the declivity of the mound, along the eastern edge of a small gully running northeast-southwest. On the eastern side of the defensive wall two houses (A and B) were adjoined, creating a dense concentration of structures. They were situated on the southern slope, on two narrow terraces running along the decline from northwest-southwest and cut into the Neolithic deposits like steps.

'House A' was located on the lower southern step. It was $13 \mathrm{~m}$ long and $7.5 \mathrm{~m}$ wide, oriented northwest-southeast, and consisted of at least five or six rooms of various size. Each room had its own stone foundation walls 0.60 to $0.80 \mathrm{~m}$ wide, with elaborate doorways preserved up to a height of $0.40 \mathrm{~m}$. The solidity of the structure, with its doubled walls, suggests that a second story could have originally been present. The plan itself shows some similarities to that of a tower-like building found at Tell Sabi Abyad (Akkermans et al. I993, 9-II, fig. 5).

Considerable quantities of ceramics were found on simple mud floors and in the fill of the rooms, among them broken but restorable pottery vessels. In a few cases joining fragments were dispersed throughout different rooms.

'House B', I2.5 $\mathrm{m}$ long and $8 \mathrm{~m}$ wide, was placed to the north of 'House A', on a second step ca. $0.60 \mathrm{~m}$ higher. Unlike 'House A', the mud-brick walls of this building, between $0.50 \mathrm{~m}$ and I $\mathrm{m}$ in width, were simply built on bare earth. The house consisted of three rooms of varying sizes - again each with its own walls - and a courtyard with an orientation following that of the terrace. The largest room $(5.80 \times 3.10 \mathrm{~m})$ was directly aligned with the defensive wall. It had only one entrance, placed at the southern end of the longer, eastern wall, leading to the courtyard. The other two rooms lay along the northern side of the yard and opened onto it. Large concentrations of potsherds were also found in the rooms of this house and on its courtyard, both in the fill and on the floors.

The northern part of the site was not as densely settled as the southern part. A large stone-paved courtyard and remnants of two houses (D and E) were unearthed there. 'House D' was the most north-

22

The Middle Assyrian resettlement of the site could have occurred under Šalmaneser I (I263-I234 BC), as was probably the case in Giricano (Radner 2004, I38). One should also stress that Nemrik had a settlement history and (probably) function similar to those of Sabi Abyad on the Balikh and Giricano in the upper Tigris valley. 

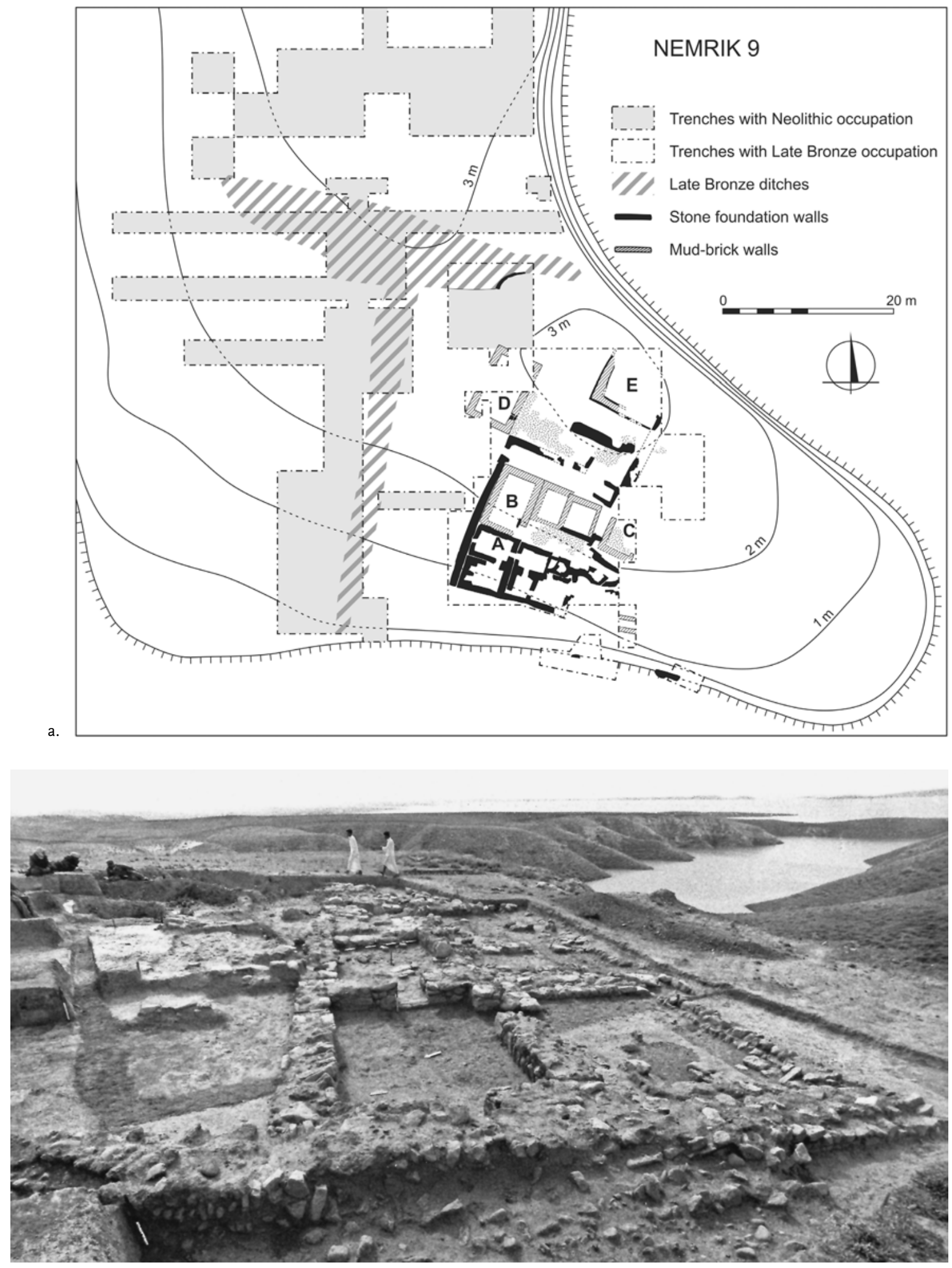

Fig. 6 | Nemrik - a. Contour map with marked trenches and Mittani-period structures, b. Miattani-period structures viewed from west Houses A and B in the foreground (Drawing: Stefan K. Kozłowski, Andrzej Reiche; digitization: Marta Momot). 


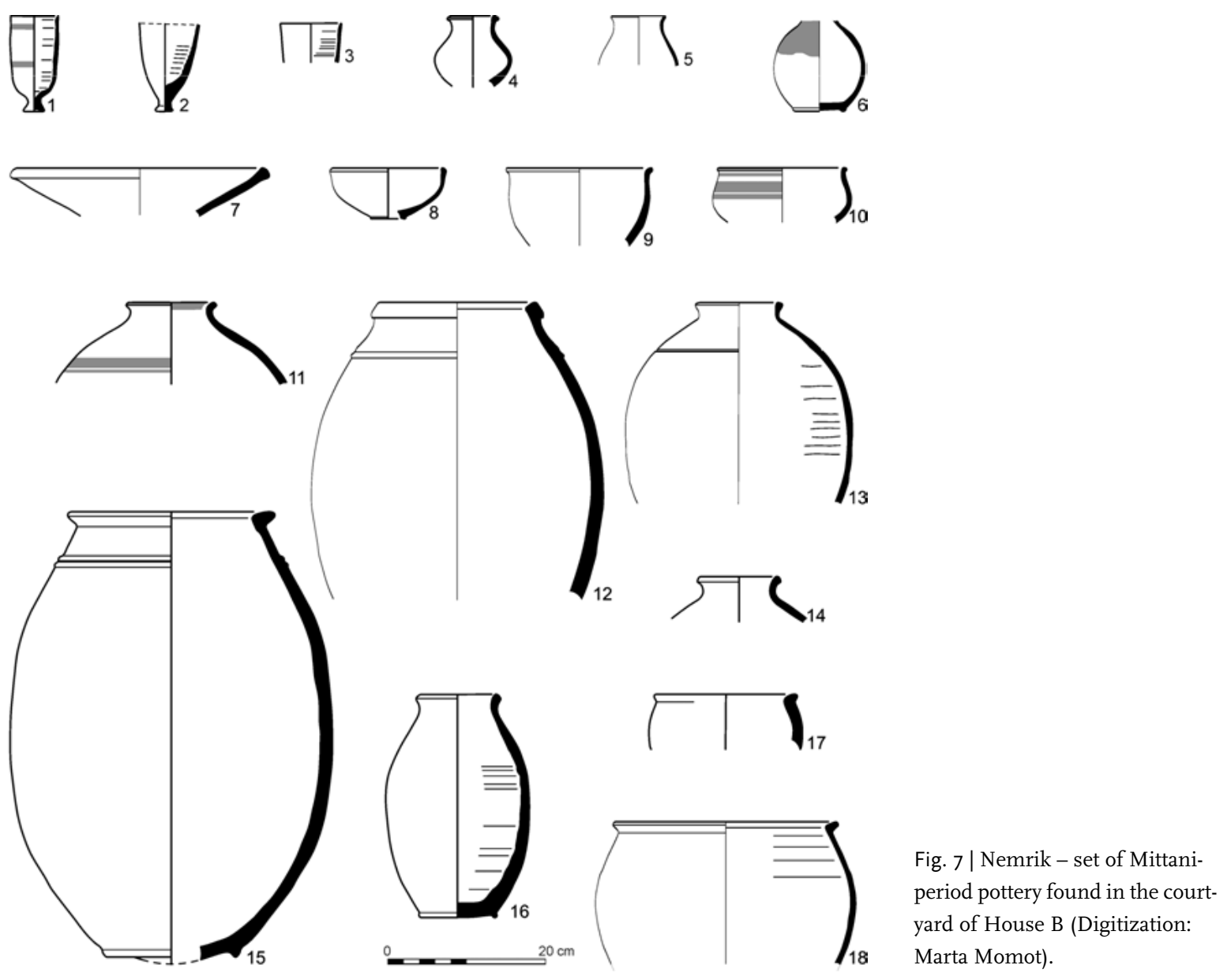

westerly building of the Mittani settlement. It was a rectangular, single-room house, $9 \mathrm{~m}$ long and $6 \mathrm{~m}$ wide and oriented northeast-southwest. An entrance placed at the southern end of the longer, eastern wall led to a courtyard paved with stone slabs (partly destroyed at its eastern end). In comparison with houses A and B, far fewer pottery vessels were found in 'House D' and its courtyard.

The fortified Mittani rural settlement found at Nemrik can be interpreted as a dimtu²3 settlement, although no written sources have been found to confirm this. The settlement seems to have been hastily abandoned, but no traces of a violent destruction were found. It is very probable that the abandonment took place at some point in the second half of the $4^{\text {th }}$ century $\mathrm{BC}$, during the reign of the Assyrian king Aššur-uballit I (I353-I3I8 BC), as he regained some of the territories controlled by the Mittani Kingdom for Assyria (Harrak I987, 3I-58). This suggestion may be strengthened by the context and (proposed) dating of the pottery.

23 For a summary of the discussion of the dimtu settlements problem see Koliński 200 I. 
Fig. 8 | Nemrik - Mittani-period pottery (Digitization: Marta Momot).
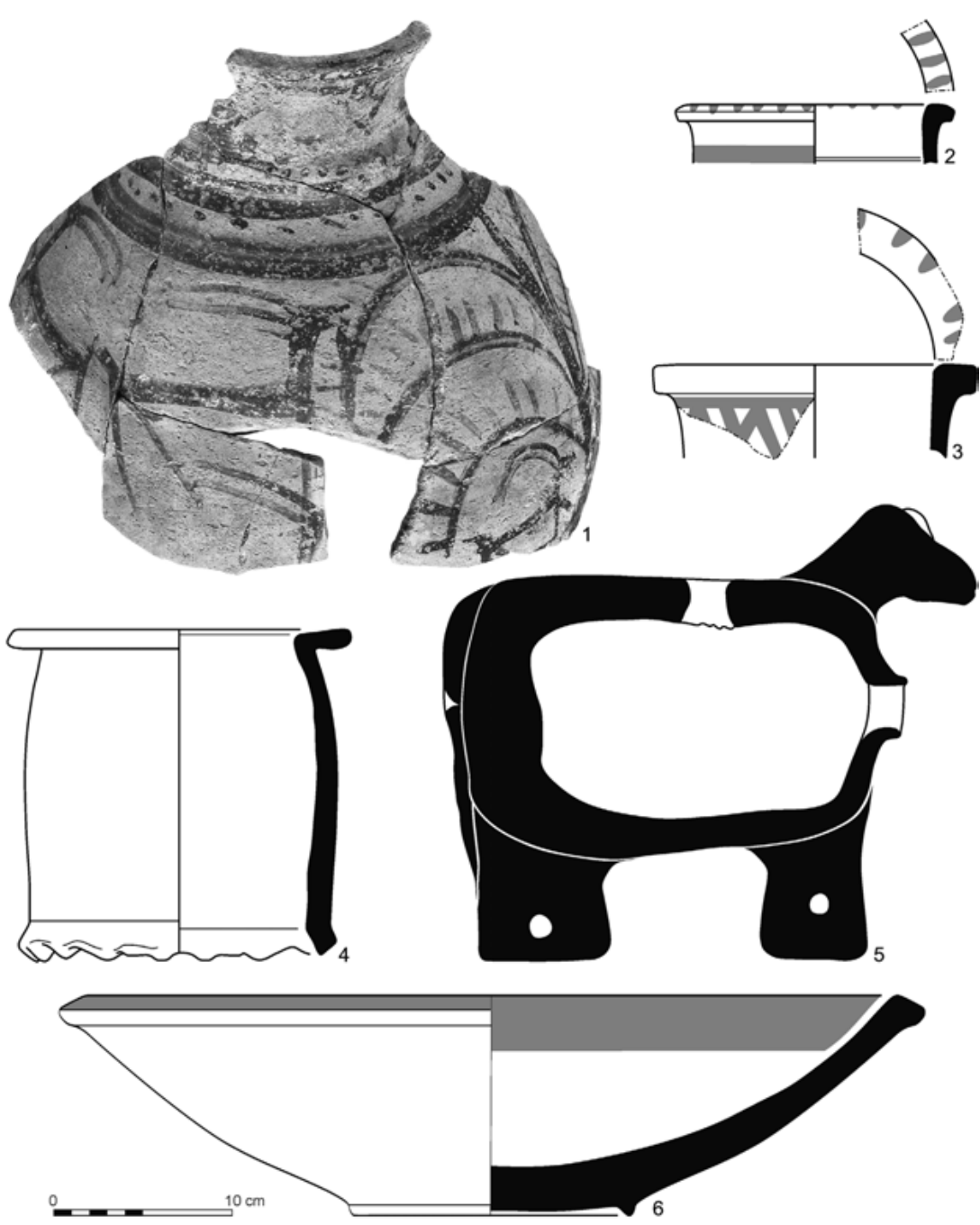

\subsection{Mittani pottery}

Large concentrations of pottery sherds were found on the floors of rooms and in the courtyards of the abandoned Mittani settlement. A wide repertoire of vessel forms was represented, ranging from beakers, differently sized bowls, jars, and cooking pots, up to storage jars. A gray ware bowl and a red-edged bowl (fig. 8:6) were also found, as were special items, such as 'pie-crust pot-stands' (fig. 8:3) and one wheeled, zoomorphic vessel in the form of a cow (?), to judge by the long, applied tail (fig 8:I). ${ }^{24}$

The Mittani pottery assemblage found at Nemrik can be attributed to a transitional period between the Middle Jazirah I A and Middle Jazirah I B periods. A feature characteristic of the Nemrik assemblage was a relatively large percentage of Younger Khabur Ware fragments found together with sherds of the

24

This characteristic kind of wheeled zoomorphic vessel was found in the Mittani levels on sites from the Euphrates to the trans-Tigris region e.g., at Tell Bazi (Otto 2006, I02, fig. 45,4c), Tell Hammam et-Turkman (Smit
I988, pl. I57, 28), Tell Brak (Oates et al. I997, nos. 663 666), Tell Hamidiye (Wäfler 2004, pl. 9,3), Tell Rimah (Postgate et al. I997, 249, pl. 99: II90, II9I), and Nuzi (Starr I937, pl. 3A). 
$\mathrm{I} 4^{\text {th }}$-century Mitanni pottery. The painted strip decoration was not only present on beakers but also on bowls as well as on small and large jars (fig. 7:I, 6, 8, I6; fig. 8:2, 4, 5). Painted Nuzi sherds were absent among the collected pottery, but the question why must remain unanswered.

An uncommon red painted decoration was found on the upper part of a jar, namely its shoulders, neck, and rim (fig. 8:2). On the shoulders, in two registers, were repeated figural scenes showing goats nibbling at bushes. On the neck and rim there were geometrical motifs including bands, dots, triangles, and strokes. The design looks like a combination of Younger Khabur Ware geometrical motifs with a unique animal and floral scene. ${ }^{25}$

\section{Conclusions}

The settlement landscape of the Mittani kingdom was diverse and unequal in different regions of the Jazirah, a result of local environmental and historical factors. Pfälzner in his study of the regional distribution (V. Die Regionale Verbreitung) of the Late Bronze Age Pottery in northern Mesopotamia distinguished seven geographical regions in which pottery of this period was found: the Lower Khabur, the Agig area, the Khabur Triangle, the Balikh Valley, the Upper Syrian Euphrates Valley, the Region of Assyria and the Trans-Tigris Region (Pfälzner I995, I69-232). The sites described in this paper were located in two of the regions: Tell Abu Hafur 'East' and Tell Arbid in the Khabur Triangle region, and Nemrik in the region of Assyria.

The three sites were part of a new settlement landscape that began to develop in northern Mesopotamia in the Mittani period and reached its apogee in the Iron Age. It was a process of change from a telldominated landscape in the Early Bronze Age to a dispersed settlement pattern in which medium-sized and small villages and farmsteads were scattered across the landscape, located in the vicinities of the large old tells but not directly on top of them. ${ }^{26}$ One has to remember that these were new settlements and that they could have partly resulted from the land-donation policy of the Mittani kings and the system of dimtu settlements.

Nemrik belonged to a group of fortified rural sites like Sabi Abyad or Giricano, all sharing a similar settlement sequence. At least in archaeological terms, the case of Nemrik supports the hypothesis put forward by Karen Radner that "the Middle Assyrian dunnu is the successor of the Hurrian dimtu" (Radner 2004, I38). The possibility that those sites had a special administrative function in the system of control over cultivable land could be the reason why they were resettled and used as dunnu settlements in the Middle Assyrian period.

Abu Hafur 'East' and Tell Arbid (sector A) in the Syrian Jazirah were medium-sized rural settlements but they seem to lack fortifications, similarly to Tell Hwesh and Tell Beydar 'Lower Town' (field J). ${ }^{27}$ However, it is often hard to answer questions about the presence of fortifications due to the poor state of preservation of a site and/or the small-scale of the excavated area. The fact that they were lo-

25 Similar motifs appear on a deep bowl from Tell Brak (Oates et al. I997, no. 456) dated to the Middle Jazirah I A period. However, one should stress the difference in the composition and style of the painted figures. See also a discussion of the so-called 'Dark on Buff Animal Ornamented Ware' by Pfälzner 2007, 240-24I.
26 A tendency to create new settlements in the vicinity of large Late Bronze Age tells and not on top of them was first noticed by Pfälzner (I995, 224). Symptoms of this transition were also observed in a detailed survey in the Beydar area (Wilkinson 2002, 362-363).

27 On the unwalled lower settlements of the Late Bronze Age, see Wilkinson 2002, 369 . 
cated near high tells, and not on top of them, seems to support the supposition that they were never intended to be fortified.

The case of rich and luxurious finds ${ }^{28}$ from the graves and from the settlement at Tell Arbid indicates that the village was inhabited by a rich landowner's family. The lack of written documents prevents us from concluding what administrative function, if any, the site could have had. An interpretation that it was a land donation made by the king is probable in light of the find of donation tablets at Tell Bazi (Sallaberger et al. 2006, 9I-92).

Another important but not frequent element of the settlement landscape of the Mittani Jazirah were towns with temples and palaces placed at the top of large tells (e.g., Tell Hamam et-Turkman, Tell Chuera, Tell Mozan, Tell Hamidiye, Tell Bari, Tell Brak). The picture resulting from excavations and surveys is thus a mixture of settlements of diverse scale, dominated by small and medium-sized villages and hamlets, with only a few large towns placed on high tells. Similar proportions are found in the text of the Assyrian king Šalmaneser I describing the conquest of Hanigalbat: I conquered nine of his fortified cult centres (as well as) the city from which he ruled and turned 180 of his cities into ruin hills. (RIMAI A.O.77.I: 75-77). One should remember that the Akkadian word alu translated as 'city' was used by the ancient scribes independently of the size or function of a settlement.

\section{Bibliography}

\author{
Akkermans, Peter M.M.G./ Limpens, José / \\ Spoor, Richard H. (I993) \\ "On the Frontier of Assyria: Excavations at Tell Sabi \\ Abyad I99I", Akkadica 84-85, I-52. \\ Anastasio, Stefano / Lebeau, Mark / \\ Savauge, Martin (eds.) (2004) \\ Atlas of Preclassical Upper Mesopotamia, (Subartu I3), \\ Turnhout.
}

\section{Anastasio, Stefano (2007) Florence. \\ Ball, Warwick / Tucker, David / \\ Wilkinson Tony J. (1989) \\ “The Tell al-Hawa Project”, Iraq 5I, I-66.}

Das Obere Habur-Tal in der Jazira zwischen dem 13. und 5. Jh. v. Chr. Die Keramik des Projektes "Prospection Archeologique du Haut-Khabur Occidental (Syrie du N.E.)",

Bieliński, Piotr (199I)

"The Third Season of Excavations in Northeast Syria, I990", in: Michał Gawlikowski / Andrzej Daszewski (eds.), Polish Archaeology in the Mediterranean II, Reports 1989-1990, Warsaw, 94-IoI.

\section{Bieliński, Piotr (2003)}

"Tell Arbid. The Seventh Season of Excavations. Preliminary Report", in: Michał Gawlikowski / Andrzej Daszewski (eds.), Polish Archaeology in the Mediterranean XIV, Reports 2002, Warsaw, 30I-3I4.

\section{Bretschneider, Joachim (1997)}

"Die Unterstadt (Feld J)" in: Marc Lebeau / Antione Suleiman (eds.), Tell Beydar, Three Seasons of Excavations (1992-1994). A Preliminary Report, (Subartu III), Turnhout, 209-243.

\section{Dosch, Gudrun (1996)}

"Houses and Households in Nuzi: the Inhabitants, the Family, and those dependent on it", in: Klaas R. Veenhof (ed.), Houses and Households in Ancient Mesopotamia. Papers read at the 4oth Rencontre Assyriologique Internationale, Leiden, July 5-8 I993, Leiden, 3OI-308.

\section{Harrak, Amir (1987)}

Assyria and Hanigalbat. A Historical Reconstruction of Bilateral Relations from the Middle of the Fourteenth to the End of the Twelfth Centuries B.C., Hildesheim-ZürichNew York. where on most of the Late Bronze Age lower settlements there was "an overall lack of fine painted Nuzi wares and late Khabur wares" (Wilkinson 2002, 370). On this basis Wilkinson stated that "it seems likely that the small sites recorded lacked any significant administrative function." 
Klein, Harald (1992)

Untersuchungen zur Typologie bronzezeitlicher Nadeln in Mesopotamien und Syrien. Wiesbaden.

Koliński, Rafał (200I)

Mesopotamian dimâtu of the Second Millennium BC., (BAR International Series Ioo4), Oxford.

Lyon, Jerry D. (2000)

"Middle Assyrian Expansion and Settlement Development in the Syrian Jazira: The View from the Balikh Valley." in: Remko M. Jas (ed.), Rainfall and Agriculture in Northern Mesopotamia. Proceedings from the third MOS Symposium in Leiden I999, MOS Studies 3, Istanbul, 89-126.

Lyonnet, Bertile / Faivre, Xavier (in print)

"L'occupation du Haut-Khabur occidental, depuis la période paléo-babylonienne jusqu'à la fin de l'époque mitanienne", in Eva Cancik-Kirschbaum / Nicole Brisch / Jesper Eidem (eds.) Constituent, Confederate, and Conquered Space. The Emergence of the Mitanni State, BerlinBoston, 43-59.

Mallowan, Max E. L. (1937)

“The Excavations at Tell Chagar Bazar and an Archaeological Survey of the Habur Region. Second Campaign, I936", Iraq 4, 9I-I53.

Maxwell-Hyslop, Kathleen R. (I97I)

Western Asiatic Jewellery c. 3000-612 B.C., London.

McDonald, Helen (1997)

"The Beads", in David Oates / Joan Oates / Helen McDonald (eds.), Excavations at Tell Brak, vol. 1: The Mittani and Old Babylonian periods, Cambridge-London, IOI-IO5.

Meijer, Diderick J. W. (1986)

A Survey in Northeastern Syria, (Publications de l'Institut historique-archéologique néerlandais de Stamboul 58), Istanbul.

\section{Novak, Mirko (1994)}

"Gewandnadeln", in: Meyer, Jan Walke, Pruß, Alexander, (eds.), Ausgrabungen in Halawa. Die Kleinfunde von Tell Halawa A, Mit Beiträgen von Egold, Andreas / Heinz, Marlies / Link, Christine / Neufang, Brigitte / Novak, Mirko, Orthmann, Winfried, (Schriften zur vorderasiatischen Archäologie 6), Saarbrücken, 237-243.

Otto, Adelheid (2006)

Alltag und Gesellschaft zur Spätbronzezeit: eine Fallstudie aus Tall Bazi (Syrien), (Subartu I9), Turnhout.
Oates, David / Oates, Joan / McDonald, Helen (with contributors) (1997)

Excavations at Tell Brak, vol.a1: The Mitanni and Old Babylonian Periods. Cambridge.

Pfälzner, Peter (1990)

"Die Keramik vom Tell Hweš, Habur-Syrien (AUBIFEAD)", Berytus 38, I37-I54.

Pfälzner, Peter (1995)

Mittanische und Mittelassyrische Keramik. Eine chronologische, funktionale und produktionsökonomische Analyse, (Berichte der Ausgrabung Tall Šêh Hamad/Dur-Katlimmu 3), Berlin.

\section{Pfälzner, Peter (2007)}

"Late Bronze Age Ceramic Traditions of the Syrian Jazirah”, in: Michel al-Maqdissi / Valerie Matoïan / Christophe Nicolle (eds.), Céramique de l'âge du Bronze en Syrie, vol. II: L'Euphrate et la région de Jézireh, (Bibliothèque Archéologique et Historique I80), Beirut, 23I-3I3.

Poidebard, Antoine (1934)

La trace de Rome dans le désert de Syrie. Le limes de Trajan à la conquête arabe. Recherches aériennes (1925-1932), (Bibliothèque Archéologique et Historique du Service des Antiquités de Syrie I8, I-2), Paris.

Postgate, Carolyn / Oates, David / Oates, Joan (1997) The excavations at Tell al-Rimah. The Pottery, Wiltshire.

Radner, Karen (2004)

Das Mittelassyrische Tontafelarchiv von Giricano/Dunnu-ša-Uzibi. Ausgrabumgen in Giricano 1, (Subartu I4), Turnhout.

\section{Rahmstorf, Lorenz (2005)}

"Terramare and Faience: Mycenaean Influence in Northern Italy During the Late Bronze Age", in: Robert Laffineur / Emanuelle Greco (eds.), Proceedings of the 1oth International Aegean Conference. Athens, Italian School of Archaeology, 14-18 April 2004, II. EMPORIA Aegeans in the Central and Eastern Mediterranean. Eageum 25 Annales d'archaéologie égéenne de l'Université de Liège et UT-PASP, Liège, $66_{3}-672$.

\section{Rahmstorf, Lorenz (2008)}

Tiryns XVI. Kleinfunde aus Tiryns. Terrakotta, Stein, Bein und Glas/Fayence vornehmlich aus der Spätbronzezeit, Wiesbaden.

Reiche, Andrzej (1990)

"Tell from the historical times", in: Stefan K. Kozłowski (ed.), Nemrik 9. Pre-pottery Neolithic Site in Iraq. (Seasons 1985-86), Warsaw, 224-234. 
Reiche, Andrzej (1997)

“Tell Abu Hafur "East”. Neuassyrische Besiedlung in der Umgebung von Hassake (Nord-Ost Syrien)", in: Hartmut Waetzoldt / Harald Hauptmann (eds.), Assyrien im Wandel der Zeiten. XXXIXe Rencontre Assyriologique Internationale, Heidelberg, 6.-10. Juli 1992, (Heidelberger Studien zum Alten Orient 6), Heidelberg, 355-364.

\section{Reiche, Andrzej (in print)}

"Late Bronze Age Pottery from Nemrik (Northern Iraq)", in: Claudia Beuger / Arnulf Hausleiter / Marta Luciani (eds.), Late Bronze Age Ceramics in Syro-Mesopotamia and Neighbouring Regions. Proceedings of the International Workshop, Berlin, 2-5 November 2006, Rahden/Westfalen, 24I-283.

\section{RIMAr:Grayson, Albert Kirk (1987)}

Assyrian Rulers of the Third and Second Millenium BC (to 1115 BC), The Royal Inscriptions of Mesopotamia: Assyrian Periods I, Toronto.

Sallaberger, Walther / Einwag, Berthold / Otto, Adelheid (2006)

"Schenkungen von Mittani-Königen an die Einwohner von Basiru. Die zwei Urkunden aus Tall Bazi am Mittleren Eufrat", in: Zeitschrift für Assyriologie und Vorderasiatische Archäologie 96, 69-IO4.

\section{Smit, Ferdinand (1988)}

“The Period VIII Pottery”, in: Maurits N. van Loon (ed.), Hammam et-Turkman I. Report on the University of Amsterdam's 1981-84 Excavations in Syria. II, Leiden, 457-583.

\section{Smogorzewska, Anna (2006)}

"Mittani Grave at Tell Arbid", in: Damaszener Mitteilungen $\mathrm{I}_{5}, 68-93$.
Starr, Richard F.S. (1937)

Nuzi. Report on the Excavations at Yorgan Tepe: 1927-1931, vol. II: Plates, Cambridge/Mass.

\section{Tessier, Beatrice (1984)}

Ancient Near Eastern Cylindrical Seals from the Marcopoli Collection, Los Angeles.

\section{Ur, Jason (2010)}

Urbanism and Cultural Landscapes in Northeastern Syria. Tell Hamoukar Survey, 1999-2001, Tell Hamoukar, vol. I, (Oriental Institute Publications I37), Chicago.

van Liere, Willem J. (1963)

"Capitals and Citadels of Bronze-Iron Age Syria in their Relationship to Land and Water", Annales Archéologiques de Syrie I3, 109-122.

van Liere, Willem / Lauffray, Jean (1954-1955)

"Nouvelle prospection archéologique dans la Haute Jézireh syrienne”, Annales Archéologiques de Syrie 4-5, I29-I48.

Wilkinson, Tony J. (2002)

"The Settlement Transition of the Second Millenium BC in the Western Khabur", in: Lamia al-Gailani Werr / John Curtis / Harriet Martin / Augusta McMahon / Joan Oates / Julian Reade (eds.), Of Pots and Plans. Papers on the Archaeology and history of Mesopotamia and Syria presented to David Oates in Honour of his $75^{\text {th }}$ Birthday, London, 36I-372.

Wäfler, Marcus (2004)

Tall al-Hamidiya 4. Vorbericht 1988-2001, (Orbis Biblicus et Orientalis, Seria Archaeologica 23), Fribourg. 
